\title{
Evaluation of Soybean [Glycine max (L.) Merill] for Phenology, Physiology, Growth, Productivity and Quality under Various Herbicidal Treatments
}

\author{
Supriya Debnath $^{1 *}$, A. S. Gontia ${ }^{1}$, Mrunal Ghogare', A. K. Jha², Anubha Upadhyay ${ }^{1}$, \\ Preeti Sagar Nayak ${ }^{1}$ and Zuby Gohar Ansari ${ }^{1}$ \\ ${ }^{1}$ Department of Plant Physiology, ${ }^{2}$ Department of Agronomy, Jawaharlal Nehru Krishi \\ Vishwa Vidyalaya, Jabalpur, Madhya Pradesh, India \\ *Corresponding author
}

\section{A B S T R A C T}

\begin{tabular}{l} 
Ke y w o r d s \\
$\begin{array}{l}\text { Propaquizafop, } \\
\text { Quizalofop, } \\
\text { Imazethapyr, Hand } \\
\text { weeding, Yield }\end{array}$ \\
\hline Article Info \\
\hline $\begin{array}{l}\text { Accepted: } \\
\text { 20 July 2020 } \\
\text { Available Online: } \\
\text { 10 August } 2020\end{array}$ \\
\hline
\end{tabular}

\section{Introduction}

Soybean [Glycine $\max (\mathrm{L}$.$) Merill] is known$ as the "GOLDEN BEAN" of the $20^{\text {th }}$ Century. It accounts approximately $50 \%$ of total production of oilseed crops in the world. It has emerged as one of the important commercial crops in many countries. Soybean is also known as the "Miracle Crop" because of its multiple uses and qualities as it has been used as pulse as well as oilseed crop. It has great potential as an exceptionally nutritive
A research experiment was conducted at the Research Farm, Department of Agronomy, JNKVV, Jabalpur (M.P.) during Kharif season of 2018 which was laid out in a Completely Randomized Block design with three replications. Seven treatments comprised of combinations as well as single application of herbicides $\mathrm{T}_{1}$ (Propaquizafop @ $50 \mathrm{gha}^{-1}$ ), $\mathrm{T}_{2}$ (Propaquizafop @ $60 \mathrm{gha}^{-1}$ ), $\mathrm{T}_{3}$ (Propaquizafop @ $75 \mathrm{gha}^{-1}$ ), $\mathrm{T}_{4}$ (Propaquizafop + Imazethapyr @ $(75+50)$ gha $\left.^{-1}\right), \mathrm{T}_{5}$ (Quizalofop@ 70 gha $^{-1}$ ), $\mathrm{T}_{6}$ (Hand weeding @ 20 and $40 \mathrm{DAS}$ ) and $\mathrm{T}_{7}$ (Weedy Check). The results revealed that treatment $\mathrm{T}_{2}$ had the longest (56.75 days) span of reproductive phase, whereas the treatment $\mathrm{T}_{4}$ had the shortest $(55.25$ days) span. $\mathrm{T}_{2}$ had the longest span of seed filling period ( 28.92 days). On the other hand, treatments $T_{4}$ and $T_{5}$ (27.33 days) indicated lowest time for seed filling duration. $T_{6}$ recorded maximum biological yield (16.44 gplant $^{-1}$ and $5479 \mathrm{kgha}^{-1}$ ) which ultimately reflected in its maximum seed yield (5.74 gplant ${ }^{-1}$ and $\left.1912 \mathrm{kgha}^{-1}\right)$. The maximum fat $(21.16 \%)$, carbohydrates $(18.76 \%)$ and ash contents were registered in treatment $\mathrm{T}_{6}$ (5.64\%), whereas crude fiber $(8.34 \%)$ and proteins $(40.12 \%)$ were registered in $\mathrm{T}_{4}$. 
Pradesh occupies the first position in area i.e. 54.09 lakh hectares and production of 59.17 lakh million tons with average productivity of $1094 \mathrm{~kg} \mathrm{ha}^{-1}$ (SOPA, 2018). In M.P., farmers apply high seed rate and narrow spacing of plant and rows to avoid risk of less plant population. Farmers in field apply more than 25 per cent more seed than needed. This is because of for poor equipment or lack of calibration. Some of it is just habit, but some producer feels that the high seeding rates are needed for better weed control. The low productivity of the crop in the state is due to several constraints, one of the major constraints in soybean production is cropweed competition (Vollmann et al., 2010); being a rainy season crop, as it is heavily infested with grasses, sedges and broadleaved weeds. The weed control practices have been exercised for the long time. Recently developed herbicides response to the weeds, crop physiological traits, productivity and quality aspects in soybean needs to be ascertained. Keeping in view of the above facts, the present investigations are undertaken

\section{Materials and Methods}

An experiment was conducted to evaluate the effect of various herbicidal treatments on phenophasic development and productivity with biochemical aspects in soybean during Kharif season of the year 2018 at the Research Farm of Department of Agronomy, JNKVV, Jabalpur (M.P.). Estimation of biochemical constituent was done in the laboratory of the Department of Plant Physiology, JNKVV, Jabalpur. The seven weed control treatments comprising of $\mathrm{T}_{1}$ (Propaquizafop @ $\quad 50 \quad$ gha $^{-1}$ ), $\quad \mathrm{T}_{2}$ (Propaquizafop @ $\quad 60 \quad$ gha $^{-1}$ ), $\quad \mathrm{T}_{3}$ (Propaquizafop @ $\quad 75 \quad$ gha $^{-1}$ ), $\quad \mathrm{T}_{4}$ (Propaquizafop + Imazethapyr @ $(75+50)$ gha $^{-1}$ ), T 5 (Quizalofop @ 70 gha $^{-1}$ ), T 6 (Hand weeding@20 and 40DAS) and $\mathrm{T}_{7}$ (Weedy
Check) were laid out in Completely Randomized Block Design with three replications. Seeds and soybean (JS 20-29) were sown in the field adopting recommended cultural practices. The phenological observations were noted from three selected and tagged plants throughout the growth period through daily visual observations.

The ash content in the seed sample was estimated according to AOAC (1980). Total carbohydrates in the samples were estimated by the method as described by Sadasivam and Manickam, 1992. The nitrogen content was estimated by micro Kjeldhal method (A.O.A.C., 1980) and the fat content in the sample was estimated by pelican equipment socs plus based on principle of Soxhlet's extraction method as described in AOAC (1980).The seed yield g plant ${ }^{-1}$ and $\mathrm{kg} \mathrm{ha}^{-1}$ was recorded after threshing, cleaning and drying the seeds. It is also known as economical yield. Biological yield is the total yield of crop including economic yield and the straw yield. The biological yield per plant was recorded after harvesting.

\section{Results and Discussion}

\section{Phenophases}

\section{Days to flower initiation}

The investigations (Table 1) indicated that treatments $\mathrm{T}_{3}, \mathrm{~T}_{5}$ and $\mathrm{T}_{6}$ (35.00 days) acquired minimum days to attain flower initiation stage which is a beneficial trait for prolonging the reproductive phase. On the other hand, treatment $\mathrm{T}_{1}$ (36.00 days) took the maximum time to record flower initiation. It is worthwhile to indicate that the treatments had not too much variation for this trait. The seed yield was positively and directly influenced by days of flower initiation (Kumar et al., 2012). 
Table.1 Phenophases in soybean during reproductive growth period under different herbicidal treatments

\begin{tabular}{|c|c|c|c|c|c|c|c|}
\hline Treatments & $\begin{array}{c}\text { Days to } \\
\text { flower } \\
\text { initiation }\end{array}$ & $\begin{array}{c}\text { Days to } 50 \% \\
\text { flowering }\end{array}$ & $\begin{array}{c}\text { Days to } \\
\text { completion } \\
\text { of flowering }\end{array}$ & $\begin{array}{l}\text { Days to pod } \\
\text { formation }\end{array}$ & $\begin{array}{l}\text { Days to seed } \\
\text { Formation }\end{array}$ & $\begin{array}{c}\text { Days to } \\
\text { physiological } \\
\text { maturity }\end{array}$ & $\begin{array}{c}\text { Days to } \\
\text { maturity }\end{array}$ \\
\hline T1 = Propaquizafop @ 50 gha $^{-1}$ & 36.00 & 39.50 & 46.75 & 55.25 & 64.25 & 76.25 & 92.42 \\
\hline T2 = Propaquizafop @ 60 gha $^{-1}$ & 35.67 & 37.67 & 48.75 & 54.25 & 63.50 & 76.75 & 92.42 \\
\hline T3=Propaquizafop @ 75 gha $^{-1}$ & 35.00 & 39.00 & 47.75 & 54.25 & 64.75 & 76.75 & 91.42 \\
\hline $\begin{array}{l}\text { T4 = Propaquizafop }+ \\
\text { Imazethapyr @ }(75+50) \text { gha }^{-1}\end{array}$ & 35.33 & 39.00 & 48.25 & 55.25 & 63.25 & 78.75 & 90.58 \\
\hline T5=Quizalofop @ 70 gha $^{-1}$ & 35.00 & 38.00 & 47.75 & 54.25 & 64.25 & 76.25 & 91.58 \\
\hline $\begin{array}{l}\text { T6= Hand Weeding @ } 20 \text { and } 40 \\
\text { DAS }\end{array}$ & 35.00 & 38.00 & 48.50 & 55.75 & 62.50 & 75.75 & 90.58 \\
\hline T7= Weedy Check & 35.00 & 39.00 & 46.25 & 52.25 & 64.50 & 75.25 & 91.08 \\
\hline SEm \pm & 0.22 & 0.34 & 0.47 & 0.46 & 0.51 & 0.47 & 0.39 \\
\hline CD $5 \%$ & 0.68 & 1.06 & 1.45 & 1.41 & 1.57 & 1.43 & 1.19 \\
\hline
\end{tabular}

Table.2 Productivity in soybean under various herbicidal treatments with biochemical constraints

\begin{tabular}{|c|c|c|c|c|c|c|c|c|c|}
\hline \multirow[t]{2}{*}{ Treatments } & \multirow{2}{*}{$\begin{array}{l}\text { Ash } \\
(\%)\end{array}$} & \multirow{2}{*}{$\begin{array}{c}\text { Crude fiber } \\
(\%)\end{array}$} & \multirow{2}{*}{$\begin{array}{c}\text { Carbohydrate } \\
(\%)\end{array}$} & \multirow{2}{*}{$\begin{array}{c}\text { Protein } \\
(\%)\end{array}$} & \multirow{2}{*}{$\begin{array}{l}\text { Fat } \\
(\%)\end{array}$} & \multicolumn{2}{|c|}{ Seed yield } & \multicolumn{2}{|c|}{ Biological yield } \\
\hline & & & & & & g plant $^{-1}$ & $\mathrm{Kgha}^{-1}$ & gplant $^{-1}$ & $\mathrm{Kg} \mathrm{ha}^{-1}$ \\
\hline T1 & 5.24 & 6.37 & 17.56 & 38.06 & 18.23 & 3.40 & 1132 & 11.15 & 3716 \\
\hline $\mathbf{T} 2$ & 4.88 & 6.14 & 17.81 & 38.43 & 19.28 & 4.92 & 1640 & 15.71 & 5237 \\
\hline T3 & 5.23 & 8.12 & 18.39 & 38.36 & 19.45 & 5.09 & 1698 & 15.69 & 5231 \\
\hline T4 & 5.12 & 8.34 & 18.48 & 40.12 & 20.57 & 5.50 & 1832 & 16.02 & 5340 \\
\hline T5 & 5.26 & 6.52 & 17.77 & 38.63 & 18.88 & 4.30 & 1434 & 12.99 & 4329 \\
\hline T6 & 5.64 & 7.65 & 18.76 & 39.3 & 21.16 & 5.74 & 1912 & 16.44 & 5479 \\
\hline T7 & 4.89 & 6.43 & 16.44 & 37.09 & 17.35 & 2.20 & 732 & 8.38 & 2792 \\
\hline SEm \pm & 0.07 & 0.23 & 0.34 & 0.45 & 0.26 & 0.23 & 49.66 & 0.50 & 109.54 \\
\hline CD $5 \%$ & 0.23 & 0.69 & 1.05 & 1.37 & 0.81 & 0.71 & 153.0 & 1.56 & 337.54 \\
\hline
\end{tabular}




\section{Days to $50 \%$ flowering}

The results showed (Table 1) that treatments $\mathrm{T}_{3}, \mathrm{~T}_{4}$ and $\mathrm{T}_{7}$ (39.00) required maximum time for completion of $50 \%$ flowering. On the other hand, lowest time was recorded in $\mathrm{T}_{2}$ (37.67). This suggested that the treatments didn't indicate a similar pattern in respect of days to flower initiation and completion of $50 \%$ flowering. The pattern of flower production, pod retention, number of flowers produced and percentage of flowers and pods abscised varied with cultivars (Zaiter and Barakat, 1995).

\section{Days to completion of flowering}

The investigations indicated (Table 1) that treatment $\mathrm{T}_{7}$ (46.25 days) took minimum time for completion of flowering, whereas treatment $T_{2}$ (48.75 days) required maximum time for completion of flowering.

The pattern from flower initiation to completion of flowering responded variably in different treatments. Flowering was started at 45 to 50 DAS, depending on genotypes (Khan and Khalil, 2010).

\section{Days to pod formation}

Treatment $\mathrm{T}_{6}$ (55.75 days) registered (Table 1) maximum time for formation of pods. On the other hand, $\mathrm{T}_{7}$ (52.25 days) needed minimum time to attain this stage. Earlier investigations showed that early pod formation resulted in high productivity which contradicts the result of present investigations.

The weed competition is one of the most important causes of yield loss (30 to 80\%) in kharif soybean and modification in source sink balance could increase assimilates distribution towards the pods (Yaduraju, 2016).

\section{Days to seed formation}

The present study showed (Table 1) that treatment $\mathrm{T}_{6}$ (62.50 days) had the earliest seed formation which is a beneficial trait for enhancing economic productivity in crop plants. However, treatment $\mathrm{T}_{3}$ (64.75 days) had delayed seed formation. Normally early seed formation is positively correlated with the seed productivity provided the seed filling rate is at optimum speed.

\section{Days to physiological maturity}

In the present study (Table 1), treatment $T_{7}$ (75.23 days) recorded the minimum and $\mathrm{T}_{4}$ (78.75 days) maximum time to achieve this stage. The real physiological maturity may be advantageous if the seeds are harvested at that particular stage (Gontia et al., 1995).

\section{Days to maturity}

The study showed (Table 1) that treatments $\mathrm{T}_{4}$ and $\mathrm{T}_{6}$ (90.58 days) attained the maturity earliest which has the advantage of avoiding shattering which sometimes takes place when the crop is harvested at the later stages. Treatment $T_{1}$ and $T_{2}$ (92.42 days) took maximum time for reaching the maturity. The seed yield plant $^{-1}$ was found to be significantly and positively correlated with days to maturity (Kumar et al., 2004). Among morphological traits under water stress conditions, the days to maturity showed the maximum reduction $(94 \%)$ (Shadakshari et al., 2014).

\section{Seed yield (g plant ${ }^{-1}$ and $\mathrm{kg} \mathrm{ha}^{-1}$ )}

The results indicated (Table 2) that all the treatments significantly increased seed yield in soybean. The results were in accordance with the findings of Deore et al., (2007), Pradhan et al., (2010) and Tuti and Das (2011). The improvement in the yield and 
economic parameters were obtained under different weed management practices in soybean (Raskar and Bhoi, 2002).

\section{Biological yield (g plant ${ }^{-1}$ and kg ha ${ }^{-1}$ )}

The present study (Table 2) indicated that the treatments $\mathrm{T}_{6}\left(16.44\right.$ gplant $^{-1}$ and $5479 \mathrm{~kg} \mathrm{ha}^{-}$ ${ }^{1}$ ) and $\mathrm{T}_{7}$ (16.02 gplant $^{-1}$ and $\left.2792 \mathrm{kgha}^{-1}\right)$ recorded higher magnitudes for biological yield. It is further mentioned that higher biological yield is not always indicative of higher economic yield as it depends on allocation of photoas similates into the vegetative or reproductive parts of the plant.

Under herbicidal treatments the highest seed yield (24.46 qha ${ }^{-1}$ ) and straw yield of soybean were also recorded in Imazethapyr @ 0.100 $\mathrm{kg}$ a.i.ha ${ }^{-1}+$ Quizalofop ethyl @ $0.075 \mathrm{~kg}$ a.i. $\mathrm{ha}^{-1}$ as PoE (Prachand et al., 2014).

\section{Biochemical constituents}

Ash (\%)

The present study (Table 2) indicated that treatment $\mathrm{T}_{6}(6.54 \%)$ recorded the highest and $\mathrm{T}_{2}(4.88 \%)$ lowest ash contents, respectively. In ten vegetable soybean genotypes along with the control the ash content was ranged from 1.49-1.74 \% (Salmani et al., 2012).

\section{Crude fiber (\%)}

In ten vegetable soybean genotypes along with the control the fiber content was ranged from 1.89-2.69\%. On the other hand, in the present investigations (Table 2), the crude fiber was found to be in the range of $8.34 \%$ in $\mathrm{T}_{4}$ and $6.4 \%$ in $\mathrm{T}_{2}$, respectively.

\section{Carbohydrate (\%)}

The present study (Table 2) indicated that the treatments $\mathrm{T}_{6}(18.76 \%)$ and $\mathrm{T}_{4}(18.48 \%)$ recorded the higher magnitudes which is beneficial trait for all the aspects. The carbohydrates provide the energy for growth and various functions in the plant. In ten vegetable soybean genotypes along with the control the carbohydrate content was ranged from 5.88-7.93 \% (Salmani et al., 2012).

\section{Protein (\%)}

The protein is very important for maintaining structural integrity of plant cells and also acts as energy source under starvation. The present study (Table 2) indicated that treatments $\mathrm{T}_{4}$ $(40.12 \%)$ and $\mathrm{T}_{6}(39.3 \%)$ had the higher magnitudes for protein contents, whereas treatment $\mathrm{T}_{7}$ recorded the minimum (37.09\%).However, Salmani et al., (2012) reported 12.32 - $14.96 \%$ protein content in ten vegetable soybean genotypes. The dry matter and yield components had strong negative association with protein content. Variety Awassa-95 (45\%) recorded significantly higher protein contents than variety Belessa-95 (40\%) (Pal et al., 2012).

\section{Fat $(\%)$}

The present investigations showed (Table 2) that treatment $\mathrm{T}_{7}$ had the maximum (21.16) fat $\%$, whereas the lowest $(17.35 \%)$ was found in $T_{7}$. The promising varieties of soybean have been found to contain the oil in the range of 19-24 percent oil concentrates increase both herbicidal effectiveness and the possibility of soybean injury (Ariunaa et al., 2016). The yield obtained by early planting was positively correlated with the oil contents (Naoki et al., 2016).

In conclusion the studies pertaining phenophases indicated that treatment $\mathrm{T}_{2}$ had the longest (56.75 days) span of reproductive phase, whereas the treatment $\mathrm{T}_{4}$ had the shortest (55.25 days) phase of reproductive phase. $T_{2}$ had the longest span of seed filling 
period (28.92 days). On the other hand, treatments $T_{4}$ and $T_{5}$ (27.33 days) indicated lowest time for seed filling duration. Treatment $\mathrm{T}_{6}$ (Hand Weeding @ 20 and 40 DAS) out yielded maximum seed yield (5.74 g plant ${ }^{-1}$ and $1912 \mathrm{~kg} \mathrm{ha}^{-1}$ ) and biological yield (16.44 gplant $^{-1}$ and 5479 kgha $^{-}$ ${ }^{1}$ ).Treatment $\quad \mathrm{T}_{4} \quad$ [Propaquizafop + Imazethapyr @ $(75+50)$ gha $\left.^{-1}\right]$ was adjudged the second in yield performance (5.50 gplant $^{-1}$ and $1832 \mathrm{kgha}^{-1}$ ) and biological yield (16.02 gplant $^{-1}$ and $\left.5340 \mathrm{kgha}^{-1}\right)$. Treatment $\mathrm{T}_{7}$ indicated the lowest yield (2.20 gplant $^{-1}$ and $732 \mathrm{kgha}^{-1}$ ) owing to poor performance of all yield components. The maximum fat (21.16\%), carbohydrates $(18.76 \%)$ and ash contents were registered in treatment $\mathrm{T}_{6}(5.64$ $\%)$, whereas crude fiber $(8.34 \%)$ and proteins $(40.12 \%)$ were in $\mathrm{T}_{4}$.

\section{Acknowledgement}

The Authors are thankful to Department of Plant Physiology and Department of Agronomy, JNKVV, Jabalpur for their helpful and constant guidance during the course of investigation.

\section{References}

AOAC.Official methods of analysis, 13th ed. Association of official Analytical chemists Washington DC, 1980, 376384.

Ariunaa $\mathrm{O}$, Otgonsuren $\mathrm{M}$ and Bayarsukh $\mathrm{N}$. Effect of chemical weed control of soybean (Glycine max L.) field in Mongolia. International Journal Advanced Research Biological Sciences 2016; 3(1): 192-198.

Deore NR, Solanke AV, Shete BT, Tambe $\mathrm{AD}$ and Nikam AS. Chemical Weed Control in Soybean. Annals of Plant Physiology. 2007; 21(1): 75-77

Gontia, A.S., Nigam, P.K., Sonakia, V.K. and Dwivedi, S.K. Identification of morphological indices of physiological maturity in soybean genotypes. Indian Journal of Agricultural Sciences 1995; 65 (6): $414-18$.

Khan A and Khalil A. Effect of leaf area on dry matter production in aerated mungbean seed.International Journal Plant Physiology and Biochemistry 2010. 2: 52-61.

Kumar R, Ravikant K and Ojha CB.Character association analysis in mung bean. Legume Research 2004; 27(1):32-36.

Liu KS. Chemistry and Nutritional Value of Soybean Components In Soybeans. Chemistry, Technology and Utilization, Liu, K.S. (Ed.).Chapman and Hall, New York, 1997, USA 25113.

MOA \& FW (Ministry of Agriculture and Farmers Welfare).2018.Directorate of Economics \& Statistics.

Naoki M, Koichiro F and Shinori T. Effects of early planting and cultivars on the yield and agronomic traits of soybeans grown in south-western Japan Plant Production Science 2016; 39-43.

Pal Daniel, Markos UR and Uragie Elias. Dry matter partitioning, nodulation and seed traits of medium and late maturing soybean varieties as affected by planting pattern and plant density. Journal of Agricultural Science and Technology 2012; 2(1):142-150.

Prachand S, Kalhapure A and Kubde K. Weed management in soybean with pre and post-emergence herbicides Indian Journal of Weed Science 2014; 47(2): 163-165.

Pradhan SS, Kolhe VS and Singh V. Studies of weed control efficiency by application of post-emergence herbicides in soybean in Chhattisgarh plain. Indian Journal of Weed Science 2010; 42(1\&2): 101-103.

Raskar BS and Bhoi PG. Bio-efficacy and 
phytotoxicity of pursuit plus herbicides against weeds in soybean (Glycine max L.). Indian Journal of Weed herbicides against Science 2002; 34(1\&2): 50-52.

Sadasivam S and Manickam A. Biochemical methods for agricultural sciences 1992; 12-13.

Salmani Z, Vijayalakhsmi D and TY. Screening of selected vegetable soybean genotypes for nutrient and anti-nutrient factors. Journal of Dairying, Foods and H.S 2012; 31(2):142-145.

Shadakshari TV, Yathish KR, Kalaimagal T, Gireesh C, Gangadhar K and Jaggal S. Morphological response of soybean under water stress during pod development stage. Legume Research 2014; 37(1): 37-46.

SOPA.The Soybean Processors Association of India 2018.Tuti MDI and Das TK. Sequential application of metribuzin on weed control, growth and yield of soybean (Glycine max) Indian Journal of Agronomy 2011; 56 (1): 57-61.

Vollmann J, Wagentristl $\mathrm{H}$ and Hartl W. The effects of simulated weed pressure on early maturing Soybean. European Journal of Agronomy 2010; 32: 24348.

Yaduraju A, Malik RK, Punia SS. Studies on carry-over effects of herbicides applied in wheat on the succeeding crop in rotation. Indian Journal of WeedScience2016; 36(1\&2): 15-18.

Zaiter HZ and Barakat SA. Flower and pod abortion in chickpea as affected by sowing date and cultivar. Canadian Journal of Plant Science 1995; 75: 321-327.

\section{How to cite this article:}

Supriya Debnath, A. S. Gontia, Mrunal Ghogare, A. K. Jha, Anubha Upadhyay, Preeti Sagar Nayak and Zuby Gohar Ansari. 2020. Evaluation of Soybean [Glycine max (L.) Merill] for Phenology, Physiology, Growth, Productivity and Quality under Various Herbicidal Treatments. Int.J.Curr.Microbiol.App.Sci. 9(08): 2176-2182. doi: https://doi.org/10.20546/ijcmas.2020.908.248 